\title{
Accounting Information System for Nonprofit Organization Based On PSAK 45 Standards
}

\author{
Yohanes Priadi Wibisono \\ Information System Program, \\ Universitas Atma Jaya Yogyakarta, Yogyakarta, Indonesia \\ e-mail : yohanes_priadi@mail.uajy.ac.id
}

\author{
Djoko Budiyanto Setyohadi \\ Magister Teknik Informatika, \\ Universitas Atma Jaya Yogyakarta, \\ Yogyakarta, Indonesia, djoko.bdy@gmail.com
}

\begin{abstract}
Now there are 4 current Accounting Standards in Indonesia, they are Pernyataan Standar Akuntansi Keuangan International Financial Reporting Standards (PSAK-IFRS), Standar Akuntansi Keuangan - Entitas Tanpa Akuntabilitas Publik (SAK-ETAP) or Financial Accounting Standards - Entities without Public Accountability, PSAK-Syariah or International Financial Reporting Standards-Sharia, dan Standar Akuntansi Pemerintah (SAP) or Government Accounting Standards. The existence of different purposes of nonprofit and commercial organizations caused the differences in presenting financial statements among users of financial statements. One derivative of the Statement of Financial Accounting Standards (PSAK) for nonprofit organizations is PSAK 45. Technology development makes the increasing of transparence and accountability for commercial and nonprofit organizations. Thus, nonprofit organizations require an accounting system as a tool to collect, store and disseminate data for planning, controlling, coordinating, analyzing and financial decision-making purposes in accordance with PSAK 45 of 2011. With the existence of computer-based accounting information system, it can further facilitate the organization in preparing the accounting reports to be more accurate and accountable. This research aims to compare the manual process of PSAK 45 accounting cycle with a software model that can implement the financial records standards for nonprofit organization as contained in PSAK 45 which is published by Ikatan Akuntan Indonesia (IAI) or Indonesian Institute of Accountants. The result of the research is the SIA or Accounting Information System (AIS) implementation result that can produce some financial transaction process in accordance with the accounting cycle and financial statement such as cash flow statement, activity report, and statement of financial position.
\end{abstract}

Keyword: Accounting Information System, PSAK 45, Nonprofit Organization

\section{INTRODUCTION}

Accounting information system composes the most important part in management information systems because accounting is stated as the language of a management [1]. Nonprofit organizations can be regarded as institutions that are founded not to seek profit only. Nonprofit organizations are organizations that are not aimed to earn profit such as religious organizations, foundations or educational institutions [2]. Nonprofit organizations also need accounting information like commercial organizations. The main purpose of nonprofit organizations' financial statement is basically the same to commercial organization, which is to provide relevant information to the activities undertaken by the organization. The differences between nonprofit and commercial organizations lie in the goals that cause discrepancies among users of financial statements and the contents of these financial statements. The differences can also be seen from the way nonprofit organizations gain resources from donations of members and other contributors who do not expect any rewards from the organization. As the result of these differences, in a nonprofit organization arises certain transactions that rarely or even never occur in a business organization, such as the receipt of a donation. However, in non-profit organizations often appear in various forms so it is often difficult to distinguish from business organizations in general [3].

PSAK No. 45 gives the notion of the purpose of a nonprofit organization's financial statements to provide relevant information. It aims to satisfy the interests of donors, members of the organization, creditors, and others who provide resources to nonprofit organizations.

The accounting information generated in the form of financial statements is indispensable to meet the interests of various parties, so that the non-profit organization financial statements should be prepared in accordance with the Statement of Financial Accounting Standards (PSAK) No. 45 on Nonprofit Financials Reporting. According to the Indonesian Institute of Accountants (2009: 45.3) in PSAK No. 45 on Nonprofit Financial Statement, Non-Profit Organization Financial Statements include the statement of financial position at the end of the reporting period, activity reports and cash flow statements for a reporting period, and notes to the financial statements.

The financial capability of an organization is communicated through a statement of financial position that provides information on assets, liabilities, net assets, and information on the relationships among the elements. This report should present separately both bonded and unrestricted assets. The accountability of the organization's board regarding its ability to manage the organization's resources received from the contributors is provided through activity reports and cash flow statements. The activity reports should provide information on changes occurred within the net asset group. The data processing itself consists of four main tasks: data collection, data manipulation, and data storing and document preparation [4]. 
2017 2nd International Conferences on Information Technology, Information Systems and Electrical Engineering (ICITISEE), Yogyakarta, Indonesia

Entering digital era, financial information's transparence demand is increasing both for users of financial statements and the policy stakeholders involved. To fulfill all the demands, financial accounting standards should be supported by information systems that are easy to access for the stakeholder who needs the financial information of the organization.

\section{REVIEW OF RELATED LITERATURE}

\subsection{Accounting Information System}

Some concepts associated with accounting information system are: Accounting information system is a data processing process providing the information that will be needed for the users of information in the business enterprises in planning, controlling and maintaining the activities of business enterprises [5]. Accounting information system is an information system collecting, processing and storing the data related to the economic activities of business enterprises for the parts to make a decision about the business enterprises [6]. Accounting is an information system to measures business activities, processes data into reports, and communicates results to the decision makers [7]. An accounting Information System has subsystems to process financial transaction and nonfinancial that directly affect the processing of financial transactions. There are three AIS subsystem, the first is Transaction Processing System that supports business operation every day with a number of documents and messages for the users of all the organizations. The second is General Ledger/ Financial Reporting System that provides traditional financial statement such as income statement, balance sheet, cash flow statement and so on. The third is Management Reporting System that provides internal management with financial statement with specific purpose and information needed for decision making [8].

Each accounting information system performs five main functions, namely data collection, data processing, database management, data control, and information generation.

As shown in Fig. 3, in general, the elements of Accounting Information Systems are users, data sources, data collection process, data processing, database management, production of information / reports, and feedback [9].

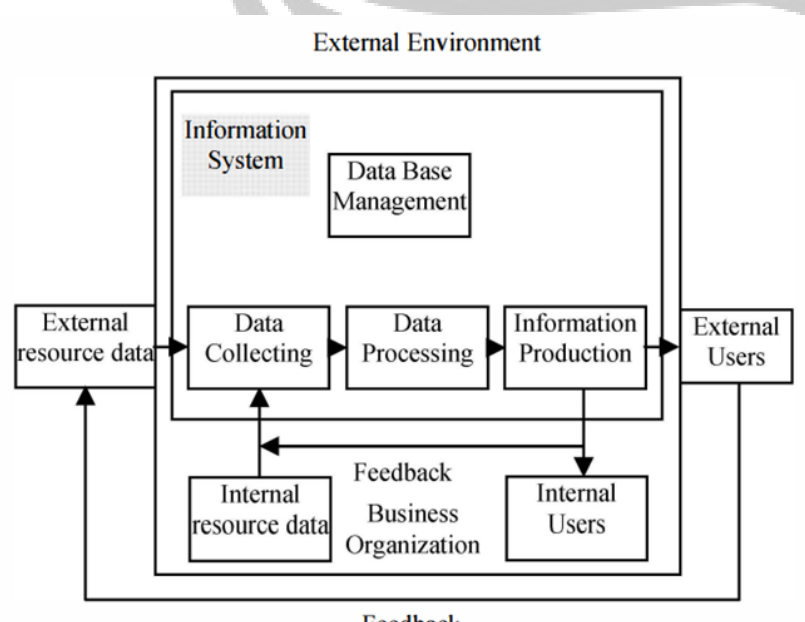

Feedback
Fig. 1. General Model of Accounting Information System

\subsection{Financial Statement}

The main purpose of financial statements according to PSAK No.45 is to provide relevant information to meet the interests of donors, members of the organization, creditors, and others who provide resources to nonprofit organizations.

Accounting Principles Board (APB) has published Statement No.4 on the purpose of financial statements [10].

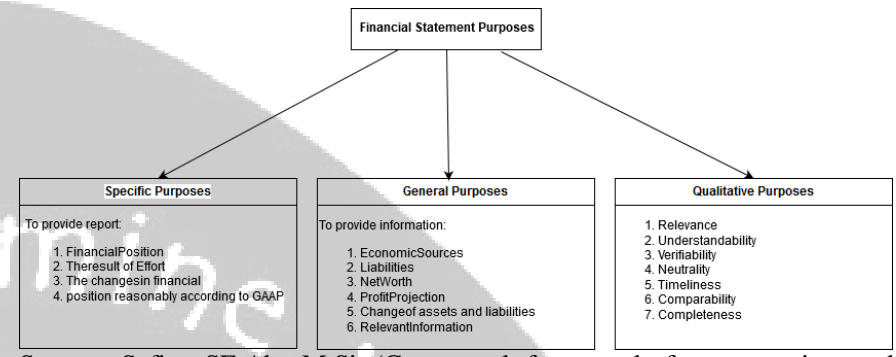

Source: Safira SE.Ak. M.Si (Conceptual framework for accounting and financial statement) Faculty of Economy University of Mercu Buana.

Fig. 2. Financial Statement Purposes according to APB Statement No. 4

\subsection{Nonprofit Organization's Financial Statement}

Nonprofit organization's financial statements according to Statement of Financial Accounting Standard No.45 includes: (1) A Financial Position Report whose purpose is to provide information on assets, liabilities and net assets and information on the relationship between the elements at a certain time. (2) Activity Reports whose purpose is to provide information on the effects of transactions and other events that alter the amount and nature of net assets; relationships between transactions and other events; and how the use of resources in the implementation of various programs or services. 3) Statement of Cash Flows to present information on cash receipts and disbursements in a period. (4) Notes of Financial Statements which are part of the inseparable financial statements as they contain detailed accounts of the accounts in the financial statements.

Table 1. Differences Characteristics of Non-profit Organizations with Commercial Companies \begin{tabular}{|l|l} 
Not For Profit Entity & Commercial Business
\end{tabular} Enterprises

1. Accept contributions from 1 . The funder is the owner sources of funds in or creditor which has an significant amounts from interest to have or refund the giver funds that do not expect return added profit or interest

\begin{tabular}{lllll}
\hline 2. & Operate to produce goods & 2 . Produce goods and
\end{tabular} and services that are not services for make a profit for looking for profit

3. The funder does not have $3 . \quad$ The funder has an interests of the interest to own or refund. 


\section{RESEARCH METHOD}

The research used mixed method both qualitative approaches and quantitative. It is useful because the issue discussed is the problem happened in some non profit organizations. They are Anak Anak Terang Foundation, Gereja Kristen Indonesia (GKI) Gejayan Yogyakarta, and Yogyakarta Red Cross. The techniques of data collecting are grouped into two, namely: main and supporting data. The main data is obtained from stakeholder by perform the depth interviews who are people involved in the financial field of the organization such as treasurer, financial admin and financial operators; while the supporting data is obtained from documents in the form of record, booking, Standard of Operation and other materials that can support in this research.

To get the good data due to the importance of this research ,data collection is performed by survey. It was done by coming directly to the place where the object is. Direct observation is accomplished especially in the department which involve in the financial organization. The data analysis techniques used in this research is descriptive-qualitative analysis. The data obtained will be analyzed and then are designed into a model of accounting information system.

Regarding the quality of the data, improving the quality of the data is performed triangulation approach by using report which is related to the problem area. The data such as feasibility study of previous accounting systems of organizations, annual report etc. Those data is explored as a secondary data. It is useful for this study since it's not only contains the needed knowledge for system development but also reduces cost significantly when the collecting data both quantitative and qualitative research is performed.

\section{DISCUSSION}

The process of preparing financial statements in non-profit organizations cannot be separated from the process of collecting evidence of transactions such as bank books, proof of payment, receipt (receipt of receipts and receipt receipts) and others. Those evidences are further recorded in the cash book, then are journalized and recorded in the ledger, posted to the trial balance, then are made into financial report. Based on the results of interviews with the object of research, the outline of the process of preparing the report can be described as follows:

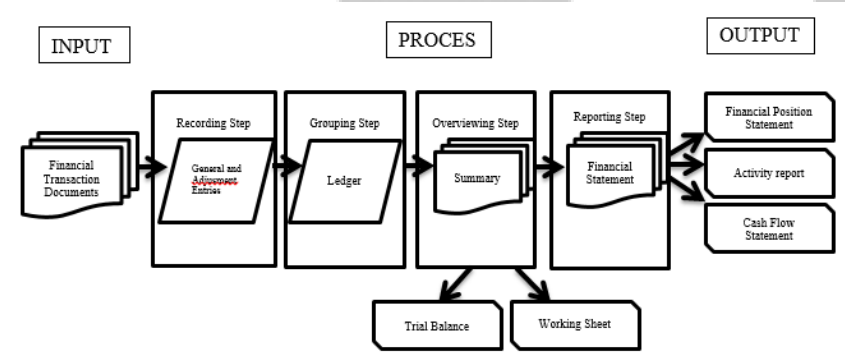

Fig. 3.The process of recording Nonprofit Organization Accounting based on the process of collecting data from the research object

The process of preparing the financial statements of nonprofit organizations is originated from evidence of receipt or proof of payment and proof of receipt from the treasurer or financial admin in the form of receipts and then recorded in the acquisition cashbook. After it is captured in the general journal, the financial admin or operator will be made monthly and annual financial statements. The financial statements made by a non-profit organization must meet generally accepted accounting principles, in accordance with accounting principles in terms of recognition, measurement, disclosure, and presentation. Recognition is the recording of an amount of rupiah into the accounting system so that the amount will affect a post and be reflected in the financial statements. So the recognition relates to the problem whether a transaction is recorded (journaled) or not [11].

Measurement is the determination of the amount of rupiah that will be attached to an object involved in a financial transaction. The amount of rupiah will be recorded as as the basic data in the preparation of financial statements [11]. While Disclosure and presentation is related to the way of disclosure or explanation of informative matters which are considered important and useful to the user other than what is stated through the main financial statements. The presentation itself sets the ways to report elements or posts in a financial statement so that the element or post is quite informative [11].

Based on the results of data collection, generally treasurers, financial administrator and financial operators are constrained by their ability or knowledge in preparing financial statements, moreover it is recording manually. They want the preparation of practical financial statements that is by doing one record automatically the financial statements can be arranged.

Basically, by using Accounting Information System, there is no change in the basic structure of the accounting cycle manually or in writing. In other words, there is always an input, process / processing, output, and feedback flow. What revealing the difference in the systems is the informational process activities in the system (the way the works are carried out) and the technologies used [12].

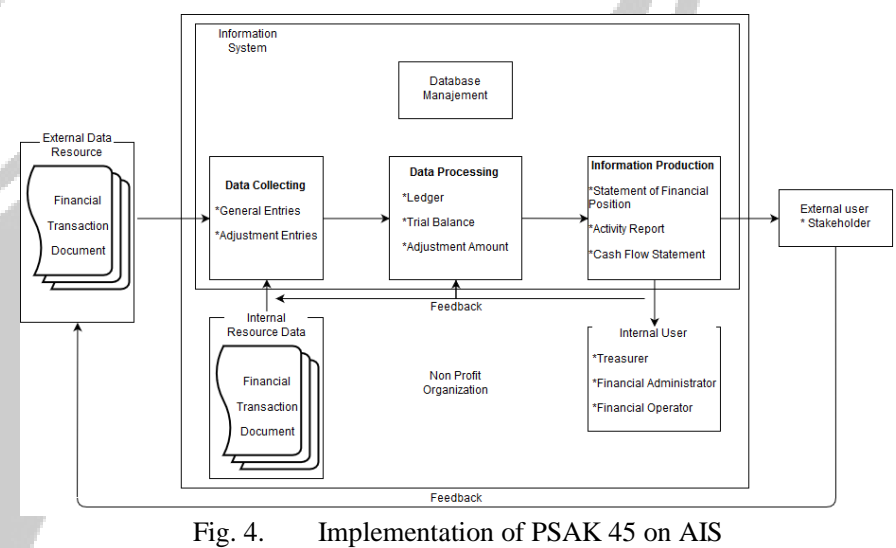

The existing problems can be overcome with the development of computer technology, especially Accounting Information Systems. However, the question is whether the system is operated manually or is already highly automatic; where it is 
2017 2nd International Conferences on Information Technology, Information Systems and Electrical Engineering (ICITISEE), Yogyakarta, Indonesia

enough with a single input, and then all data processing to the report is available in accordance with PSAK 45.

\section{CONCLUSION}

The conclusion of the research in general is the process / stage of accounting cycle manually / written is not much different from using AIS.

Table 2. Differences in work processes between manual accounting and AIS

\begin{tabular}{|c|c|c|}
\hline Accounting Steps & $\begin{array}{c}\text { Manual } \\
\text { Accounting }\end{array}$ & $\begin{array}{c}\text { Accounting } \\
\text { Information } \\
\text { System }\end{array}$ \\
\hline $\begin{array}{l}\text { Input (Financial } \\
\text { Transaction Document) }\end{array}$ & Manual & Manual \\
\hline $\begin{array}{cl}\text { Proces } & \text { Recording Step) } \\
\text { - } & \text { General } \\
& \text { enteries } \\
\text { - } & \text { Adjustment } \\
\text { enteries }\end{array}$ & $\begin{array}{l}\text { Manual } \\
\text { Manual }\end{array}$ & $\begin{array}{l}\text { Automatic } \\
\text { Automatic }\end{array}$ \\
\hline $\begin{array}{c}\text { Proces (Grouping step) } \\
\qquad \quad \text { Ledger }\end{array}$ & Manual & Automatic \\
\hline $\begin{array}{l}\text { Proces (overviewing } \\
\text { step) } \\
\text { - Trial balance } \\
\text { - Working Sheet }\end{array}$ & $\begin{array}{l}\text { Manual } \\
\text { Manual }\end{array}$ & $\begin{array}{l}\text { Automatic } \\
\text { Automatic }\end{array}$ \\
\hline $\begin{array}{c}\text { Proces (reporting step) } \\
\qquad \quad \begin{array}{l}\text { Financial } \\
\text { statement }\end{array}\end{array}$ & Manual & Automatic \\
\hline $\begin{array}{cl}\text { Output } & \\
\text { - } & \text { Financial } \\
& \text { position } \\
& \text { statement } \\
\text { - } & \text { Activity report } \\
\text { - } & \text { Cash flow } \\
& \text { statement } \\
\end{array}$ & $\begin{array}{l}\text { Manual } \\
\text { Manual }\end{array}$ & $\begin{array}{l}\text { Automatic } \\
\text { Automatic }\end{array}$ \\
\hline
\end{tabular}

*Manual $=$ done by humans

*Automatic $=$ done by computer

The desire of AIS operators in the convenience of recording accounting with just enough once input can also fulfilled. With only once journal input, then automatically all forms into financial statement. The stages of the process in the accounting cycle such as recording, grouping, summarizing and reporting can be performed and processed automatically by AIS.

The problems faced by financial stakeholders in non-profit organizations is they are constrained by their ability or knowledge in preparing accounting reports; where it can be overcome with Accounting Information Systems that have been adjusted to the standard PSAK 45.

Processed automatically by AIS makes the job more effective and efficient and the financial statements are more accurate and accountable

\section{References}

[1] Allahverdi, M. 2011. A general model of accounting information systems. In Application of Information and Communication Technologies (AICT), 2011 5th International Conference on (pp. 1-5). IEEE.

[2] Jusup, A. H., 2005. Dasar-dasar Akuntansi. STIE-YKPN. Yogyakarta.

[3] Ikatan Akuntan Indonesia (IAI). 1998. Standar Akuntansi Keuangan.Jakarta: Penerbit Salemba

[4] McLeod, Raymond, Jr. 2001. Sistem Informasi Manajemen Edisi Ke-7. Jakarta: Penerbit Salemba.

[5] Marshall B. Ronmey, Paul John Steinbart, Barry E. Cushing, Accounting Information Systems, Seventh Edition, Addison-Wesley Publishing CO.,1997, p.2.

[6] David, SJulie et ai, "The Research Pyramid:A Framework For Accounting Information System Research", Journal of Information System, VoI.I3, No.1, Spring 1999, p. 7-30.

[7] Charles T.Horngren dan Walter T. Harrison Jr.2007. Akuntansi Jilid Satu . Edisi Tujuh. Jakarta: Penerbit Erlangga.

[8] Hall, James A. 2001. 3th edition. Accounting Information Systems. Cincinnati: Shout-Western College Publishing.

[9] James A. Hall, "Accounting Information Systems",West Publishing Company, p.11-15.

[10] Accounting Principle Board (APB). 1970. Statement No. 4. Basic Conceptsand Accounting Principles Underlying Financial Statement of Business Entrprise. United States of America

[11] Suwardjono, 2008. Teori Akuntansi : Perekayasaan Pelaporan Keuangan, Edisi Ketiga. Yogyakarta : BPFE Yogyakarta.

[12] Arman Aziz Karagül, "Bilgi Yönetimi, Kurumsal Kaynak Planlamasi ve Muhasebe Bilgi Sistemi İlişkisi Çerç evesinde Muhasebe Eğitimi", XXIV. Türkiye Muhasebe Eğitimi Sempozyumu Tebliğleri Kitabi, April 2005, p. 59-87. 
LEMBAR

HASIL PENILAIAN SEJAWAT SEBIDANG ATAU PEER REVIEW KARYA ILMIAH : PROSIDING INTERNASIONAL

Judul Karya Ilmiah (Artikel)

Penulis Karya Ilmiah Identitas Karya Ilmiah

Hasil Penilaian Peer Review :
: Accounting Information System for Nonprofit Organization Based On PSAK 45 Standards

: Yohanes Priadi Wibisono,S.T.,M.M.

: a. Nama Prosiding: ICITISEE $2^{\text {nd }}$

b. Pelaksanaan : 2017

c. Penyelanggara : Universitas AMIKOM Yogyakarta

d. url dokumen : -

\begin{tabular}{|c|c|c|c|}
\hline \multirow[b]{2}{*}{$\begin{array}{l}\text { Komponen } \\
\text { Yang Dinilai }\end{array}$} & \multicolumn{2}{|c|}{ Nilai Maksimal Prosiding } & \multirow[b]{2}{*}{$\begin{array}{l}\text { Nilai Akhir Yang } \\
\text { Diperoleh }\end{array}$} \\
\hline & Internasional & Nasional & \\
\hline a. Kelengkapan unsur isi buku ( $10 \%)$ & 1,5 & & 1,5 \\
\hline $\begin{array}{l}\text { b. Ruang lingkup dan kedalaman } \\
\text { pembahasan }(30 \%)\end{array}$ & 4,5 & & 3,5 \\
\hline $\begin{array}{l}\text { c. Kecukupan dan kemutahiran } \\
\text { data/informasi dan metodologi }(30 \%)\end{array}$ & 4,5 & & 3,5 \\
\hline $\begin{array}{l}\text { d. Kelengkapan unsur dan kualitas penerbit } \\
(30 \%)\end{array}$ & 4,5 & & 4,5 \\
\hline Total $=(100 \%)$ & 15 & & 13 \\
\hline $\begin{array}{l}\text { Kontribusi Pengusul (Penulis Pertama } \\
\text { dari dua penulis) }\end{array}$ & & & $\begin{array}{c}7,8 \\
(60 \% \times 13) \\
\end{array}$ \\
\hline \multirow[t]{4}{*}{ Komentar Peer Review } & \multicolumn{3}{|c|}{ 1. Tentang kelengkapan unsur isi buku: } \\
\hline & \multicolumn{3}{|c|}{$\begin{array}{l}\text { 2. Ruang lingkup dan kedalaman pembahasan: pembahasan } \\
\text { kurang lengleap \& kurang komprehen sif }\end{array}$} \\
\hline & \multicolumn{3}{|c|}{ 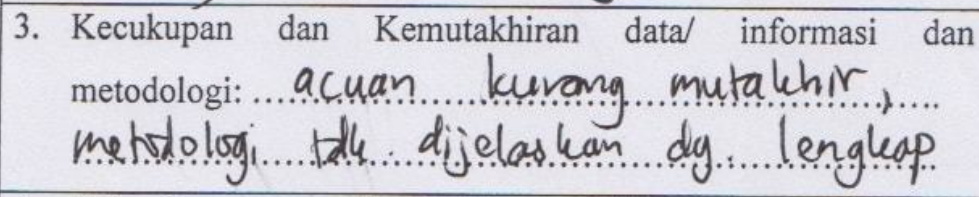 } \\
\hline & \multicolumn{3}{|c|}{ 4. Kelengkapan unsur dan kualitas penerbit: ...................... } \\
\hline
\end{tabular}

$$
\text { Yogyakarta, ....................18 }
$$

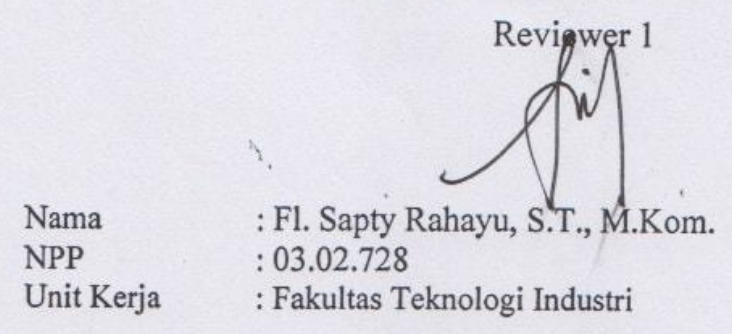




\section{LEMBAR \\ HASIL PENILAIAN SEJAWAT SEBIDANG ATAU PEER REVIEW KARYA ILMIAH : PROSIDING INTERNASIONAL}

Judul Karya Ilmiah (Artikel)

Penulis Karya Ilmiah Identitas Karya Ilmiah

Hasil Penilaian Peer Review :
: Accounting Information System for Nonprofit Organization Based On PSAK 45 Standards

: Yohanes Priadi Wibisono,S.T.,M.M.

: a. Nama Prosiding: ICITISEE $2^{\text {nd }}$

b. Pelaksanaan : 2017

c. Penyelanggara : Universitas AMIKOM Yogyakarta

d. url dokumen :-

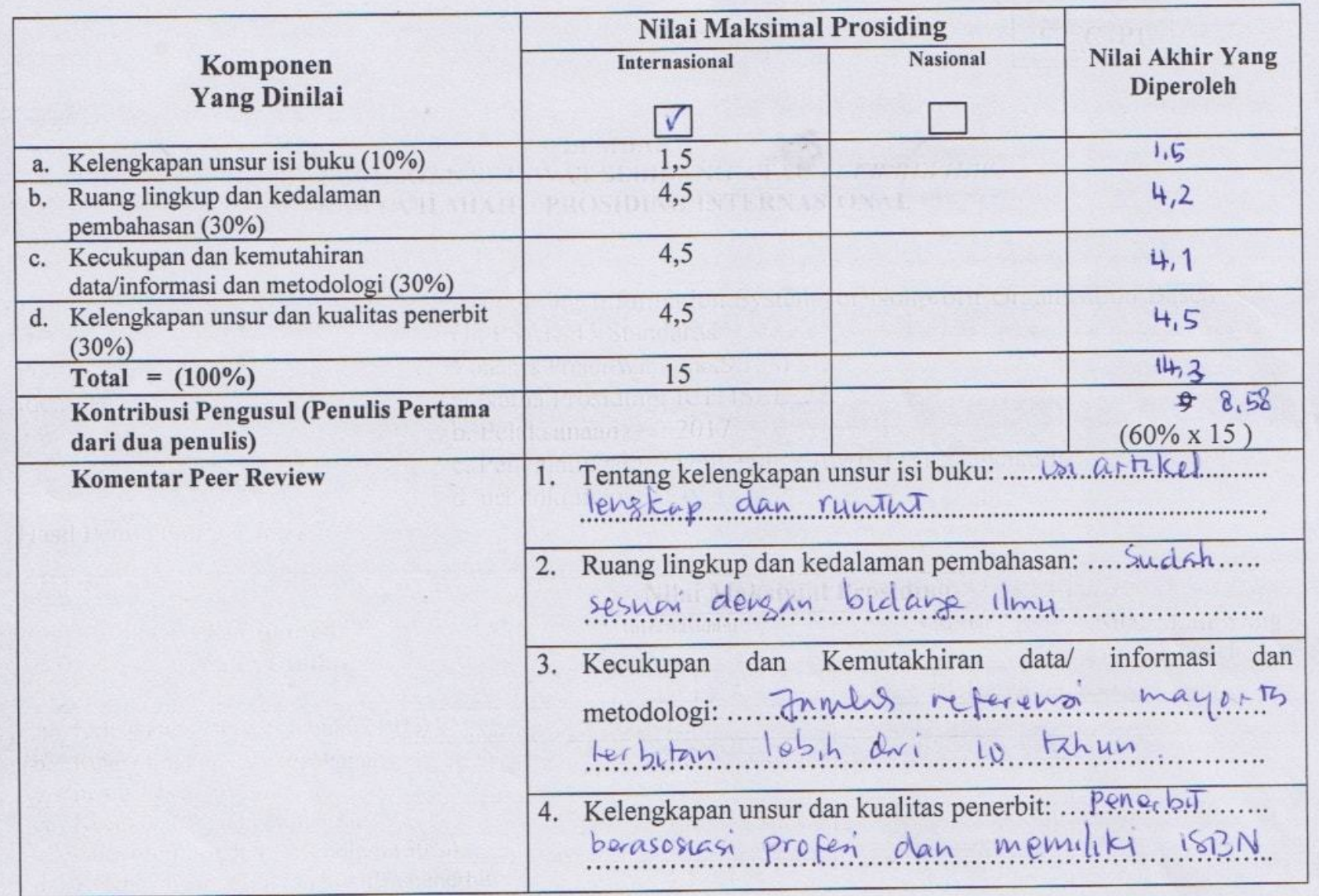

$$
\begin{gathered}
\text { Yogyakarta, .................................. } \\
\text { Reviewer } 2 \\
\text { Be }
\end{gathered}
$$

Nama : Benyamin Langgu Sinaga, S.T., M.Comp.Sc.

NPP : 07.94.517

Unit Kerja : Fakultas Teknologi Industri 